\title{
SEVERAL INFLUENCES OF SYSTEM INFORMATION QUALITY TO USER SATISFACTION AND ITS IMPLICATION ON INDIVIDUAL PERFORMANCE (Empirical Study International Freight Forwarding)
}

\author{
Sri Anjarwati and Apollo \\ Mercu Buana University, Jakarta Indonesia \\ Email: anjarjani1@gmail.com
}

ARTICLE INFO

Article History:

Received 22 May 2018

Revised 15 June 2018

Accepted 15 July 2018

JEL Classification:

$\mathrm{J} 01$

Keywords:

System Information,

Perceived Usefulness,

Satisfaction, and

Performance

\begin{abstract}
Research aimed to analyze several influences of system quality, information quality and perceived usefulness to user satisfaction on financial accounting software and its impact on individual performance. Sampling technique was using purposive sampling based on questionnaires distributed to users of financial accounting software who work at international freight forwarding. The number of samples was 200 respondents. The analytical method used was Structure Equation Models (SEM) with Lisrel 8.75 full version. The result of study showed that system quality and information quality have significant influenced the perceived usefulness. System quality, information quality, and perceived usefulness have significant influenced to user satisfaction. User satisfaction had significant influenced to individual performance. The highest influence from overall model was shown by the influence of system quality on perceived usefulness.
\end{abstract}

\section{INTRODUCTION}

Today, information is very quickly obtained because it is supported by information technology. Information systems have been reporting on an enterprise since the 2000s of e-commerce era and ecommerce using the internet. Accounting information system begins to be computerbased. Accounting software begins to be created to accelerate the performance of financial reporting, such as general ledger, MYOB, Accurate, Zahir and others. About 2010, software was starting to integrate between parts and between activities within the company, thus minimizing the work inputted two or more times. An integrated information system can save company's costs, improve performance, and prevent fraud, or budget lapses. However, implementation of information system in Indonesia is still not effective and not yet integrated. Nainggolan (2012), as Chairman of the Board of Directors of Sabang-Merauke Circle (CMC), stated that corruption occurs due to inefficient, intransparent, and unaccountable state administration system.

Information technology companies predict the use of the system, especially integrated information system, will increase until 2020. One example of integrated information system software is Enterprise Resource Planning (ERP) which is used to plan and manage enterprise resources. The following data illustrates the growth of integrated technology system between parts. 
Sri Anjarwati: Several Influences of...

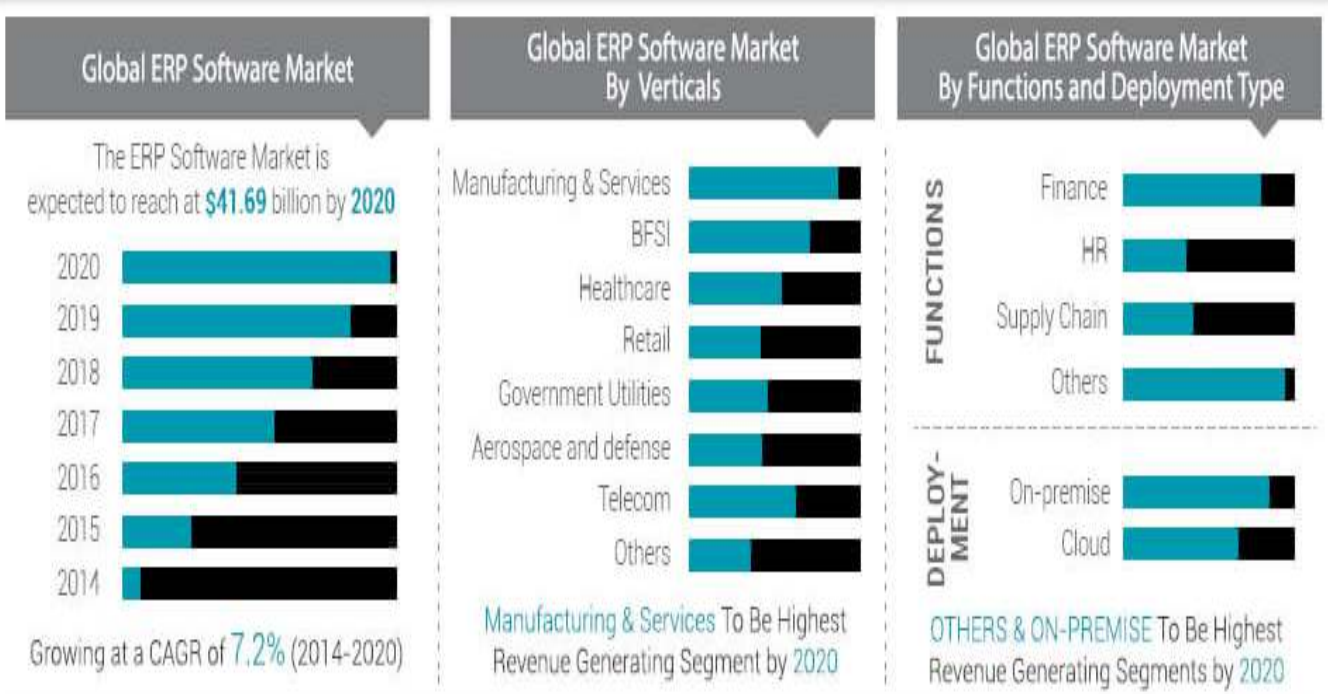

Source: Global ERP, https://www.alliedmarketresearch.com/ERP-market.

Figure 1. ERP Software Market for 2013-2020

Figure 1 shows the demand for software will increase until 2020, and the most widely used part or function is finance. Information systems are designed to meet user satisfaction and needs. Also, their impacts can improve performance. In accordance with the results of research by Hadji and Degoulet (2016), there is a causal relationship in the model between significant information system and information system quality to perceived usefulness and system to user satisfaction. Istianingsih dan Utami (2009) stated in their research that system quality, information quality, and service quality have significant positive influence on the satisfaction of information systems, and users satisfaction significantly influence on individual performance. Meanwhile research results by Wu and Wang (2006), system quality have not significant influence on perceived usefulness. Roky and Al Meriouh (2015) also stated that user satisfaction to individual impact is not proved significant.

This research was conducted at international freight forwarding company. Formulations of the problem are: 1) Do the system quality and information quality have a significant influence on perceived usefulness?; 2) Do the system quality, information quality and perceived usefulness have a significant influence on user satisfaction?; 3) Does the user satisfaction have a significant influence on individual performance?

\section{LITERATURE REVIEW \\ System Quality}

The quality system according to Romney and Steinbart (2015) is a chain of two or more unrelated components that interact to achieve a goal. On the other hand system quality based on theoretical opinions is stated by Hall (2007), Gelinas and Dull (2012). The used dimensions as a measurement are the ease of use, response time, friendly use and reliability (Bailey and Pearson, 1983).

\section{Information Quality}

According to information quality theory by Laudon and Laudon (2015), Gellinas and Dull (2012), Negash et al. (2003), quality information is data that presented in a useful form of decision-making activities. The used 
dimensions in the research are accurate, relevance, secure, and economical, (DeLone and McLean, 1992, Heidmann, 2008). Previous research by Hadji and Degoulet (2016), Istianingsih and Wijanto (2008), quality system affects the perception of benefits. From the theory above, it can be formulated hypotheses as follows:

$H_{1}$ : System quality has significant influence to perceived usefulness.

\section{$\mathrm{H}_{2}$ : Information system quality has significant influence to perceived usefulness.}

\section{Perceived Usefulness}

Perceived usefulness is a perception where one believes that the use of a particular subject will improve one's work performance, (Davis, 1989, Jogiyanto, 2007). Dimensional perceived usefulness is used to ease the understanding, based on useful information (Davis, 1989, DeLone and McLean, 2003). The results of previous research showed that perceived usefulness had an effect on the individual performance (Wu and Wang, 2006). Thus hypotheses were proposes as below.

\section{$\mathrm{H}_{3}$ System quality has significant influence to user satisfaction.}

$\mathrm{H}_{4}$ : Information quality has significant influence to user satisfaction.

$H_{5}$ : Perception usefulness has significant influence to software user satisfaction.

\section{User Satisfaction}

User satisfaction is the response and feedback that users show after using the information system (DeLone and McLean, 2003, Stacie et al., 2008). Dimensions that used by Hall (2007) are content, accuracy, format, completeness, timeliness, relevance. The results of previous research by Sirsat and Sirsat (2010), Istianingsih and Utami (2009), stated that user satisfaction has an effect on individual performance. Development of the hypotheses is as follows.

\section{$H_{6}$ : User satisfaction has significant influence to individual performance.}

\section{Individual Performance}

According to Stacie et al. (2008) explains the overall benefit of individual performance is the degree to which information systems contribute to the success of individuals, groups, organizations, industries and nations.

DeLone and McLean (2003) stated that indicators for measuring the overall benefits are cost savings and time savings, including productivity, efficiency and performance effectiveness. The measurement indicators of individual performance according to Davis (1993) are as follows: quicker rate of work, job performance, increasing productivity, effectiveness, making job easier, usefulness in job.

\section{Research Model \\ The research framework model is illustrated as follows.}




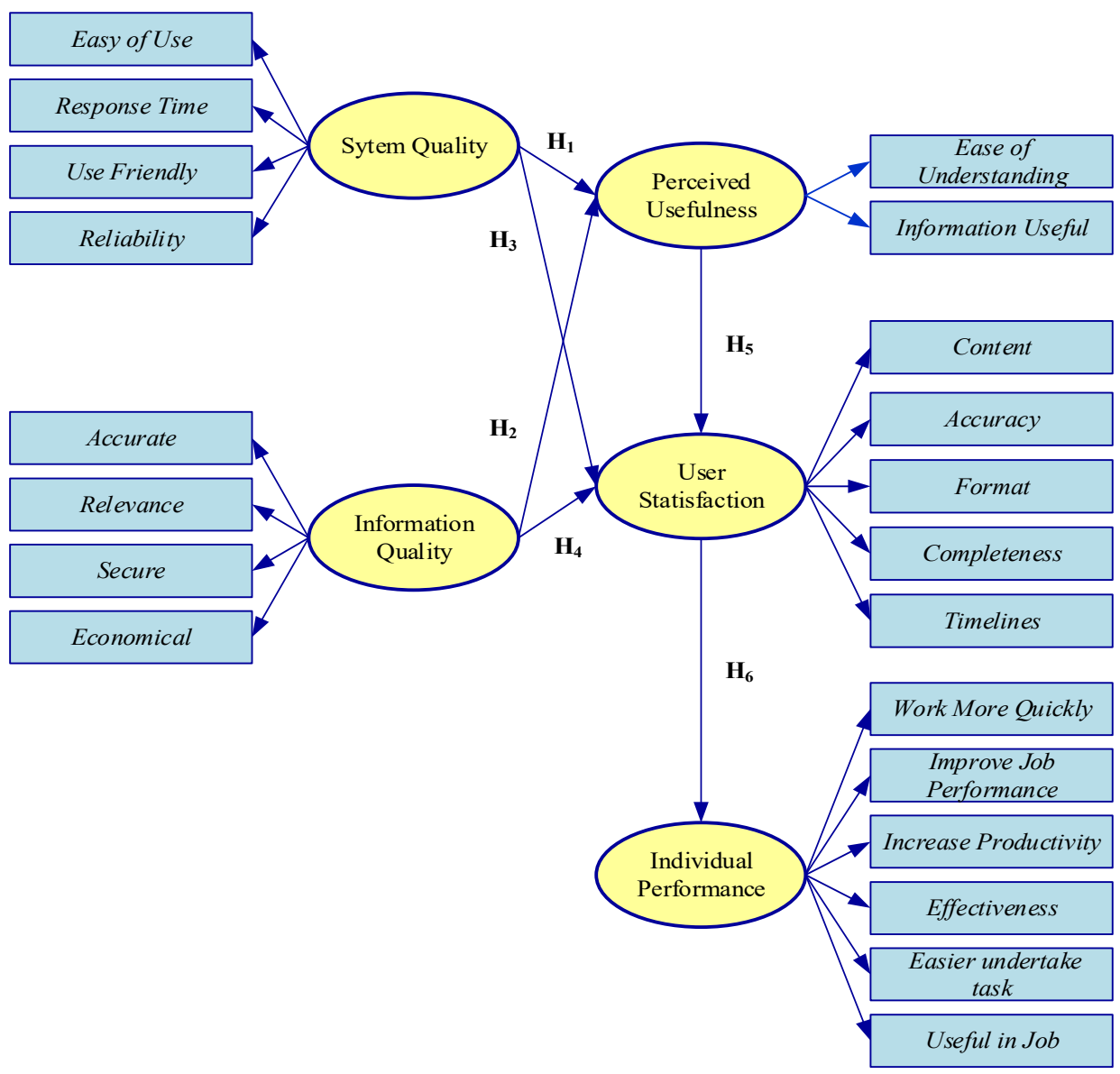

Figure 2. Research Model

\section{METHODOLOGY}

The type of research method was quantitative method using primary data.

\section{Data Collection Techniques}

Questionnaire development was based on operational variables and theory. Instrument tool was used sheet questionnaires. Then, pretest survey was done to test the validity of questionnaires, if the questionnaire was needed to be revised. In the next step, respondent was selected and data was collected. Then, the next stage was data processing and analysis.

\section{Operational Definitions of Variabel}

The definition of operationalization of variables is presented in the Table 1.

Table 1. Operational Definitions of Variable

\begin{tabular}{cl|l|clr}
\hline No & \multicolumn{1}{c}{ Variable } & \multicolumn{1}{c}{ Dimension } & Indicator & Scale \\
\hline \multirow{2}{*}{1} & $\begin{array}{l}\text { System Quality } \\
\text { Romney and }\end{array}$ & Ease of use & 3 & $\begin{array}{l}\text { DeLoan and } \\
\text { McLean (1992) }\end{array}$ & Interval \\
\cline { 2 - 3 } & Response Time & 2 &
\end{tabular}




\begin{tabular}{|c|c|c|c|c|c|}
\hline No & Variable & Dimension & Indicator & & Scale \\
\hline & \multirow[t]{2}{*}{ Steinbart (2015:3) } & Use Friendly & 3 & \multirow{2}{*}{$\begin{array}{l}\text { Bailey and } \\
\text { Pearson (1983) }\end{array}$} & \\
\hline & & Reliability & 3 & & \\
\hline \multirow[t]{4}{*}{2} & \multirow{4}{*}{$\begin{array}{l}\text { Information Quality } \\
\text { Laudon and Laudon } \\
\text { (2015) }\end{array}$} & Accurate & 2 & \multirow{4}{*}{$\begin{array}{l}\text { Stacie et al. } \\
\text { (2013) } \\
\text { Bailey and } \\
\text { Pearson (1983) }\end{array}$} & \multirow[t]{4}{*}{ Interval } \\
\hline & & Relevance & 2 & & \\
\hline & & Secure & 2 & & \\
\hline & & Economical & 3 & & \\
\hline \multirow[t]{2}{*}{3} & \multirow{2}{*}{$\begin{array}{l}\text { Perceived } \\
\text { Usefulness } \\
\text { Davis et al. (1989) }\end{array}$} & Ease of understanding & 3 & \multirow[t]{2}{*}{ Davis (1989) } & \multirow[t]{2}{*}{ Interval } \\
\hline & & Information useful & 3 & & \\
\hline \multirow[t]{5}{*}{4} & \multirow{5}{*}{$\begin{array}{l}\text { User Satisfaction } \\
\text { DeLone and } \\
\text { McLean (2003) }\end{array}$} & Content & 2 & \multirow{5}{*}{ Hall (2007) } & \multirow[t]{5}{*}{ Interval } \\
\hline & & Accuracy & 2 & & \\
\hline & & Format & 2 & & \\
\hline & & Completeness & 2 & & \\
\hline & & Timeliness & 2 & & \\
\hline \multirow[t]{6}{*}{5} & \multirow{6}{*}{$\begin{array}{l}\text { Individual } \\
\text { Performance } \\
\text { Stacie et al. (2008) }\end{array}$} & Work more quickly & 2 & \multirow[t]{6}{*}{ Davis (1993) } & \multirow[t]{6}{*}{ Interval } \\
\hline & & $\begin{array}{l}\text { Improve job } \\
\text { performance }\end{array}$ & 2 & & \\
\hline & & Increase productivity & 2 & & \\
\hline & & Effectiveness & 2 & & \\
\hline & & Easier undertake task & 2 & & \\
\hline & & Useful in job & 1 & & \\
\hline \multicolumn{6}{|c|}{ Total Questionnaires 47 Item } \\
\hline
\end{tabular}

\section{Sample Collection Techniques}

In this research, questions were using the rating scale were based on 5-Likert rating scale from strongly disagree to strongly agree,
Sekaran (2013). The step and sample collection techniques are described in the Table 2.

Table 2. Sample Collection Techniques

\begin{tabular}{ll}
\hline \multicolumn{1}{c}{ Step } & \multicolumn{1}{c}{ Description } \\
\hline Population target & 305 employee (national district) \\
Frame Sample & 241 employee (using of software) \\
Time period & September 2017-November 2017 \\
Sampling technique & Purposive sampling, Sekaran (2003) \\
Sample criteria & Employee from International Freight Forwarding Company, \\
& Accounting and Finance Department, Using of Software Accounting \\
Number of samples & Finance \\
& - Maximum Likelihood Estimate can be used with minimum 100 \\
& samples \\
& -The overall research model uses 5 latent variables, which are
\end{tabular}


Sri Anjarwati: Several Influences of...

\begin{tabular}{cl}
\hline Step & \multicolumn{1}{c}{ Description } \\
\hline & consists of 21 dimensions (21 x 5=105 sample), Chou and Bentler \\
& (1995), (Hair et al., 2006), Wijanto (2015). \\
\hline
\end{tabular}

\section{Data Analysis Techniques}

Data analysis technique of causal correlation was using Structural Equation Modeling (SEM) with Lisrel 8.75 full version software. Analyzes and tests of the proposed research model of employee structural equation modeling by Wijanto (2015), Ghozali (2014), Hair et al. (2006).

\section{RESULT AND DISCUSSION}

Analysis of the results of this research will be in the form of outlines in the figure and table.

\section{Descriptive Object Research}

241 questionnaires were distributed to respondents for survey and only 200 questionnaires were returned, so response rate of questionnaires distribution was $83 \%$.
Test Result validity and Reliability

Pretest was conducted on 20 employees at the observed company which is domiciled in Jakarta. Test results validity was done for 47 indicators and there were three invalid data. Validity for 21 dimensions also showed as valid. It constructed the test result with good reliability.

\section{Structural model analysis results}

The results of the analysis and hypothesis are shown in the overall model. The Goodness of fit test results on the overall structural model showed that there were six indicators of good fit. Therefore, the overall fit for structural model was sufficient.

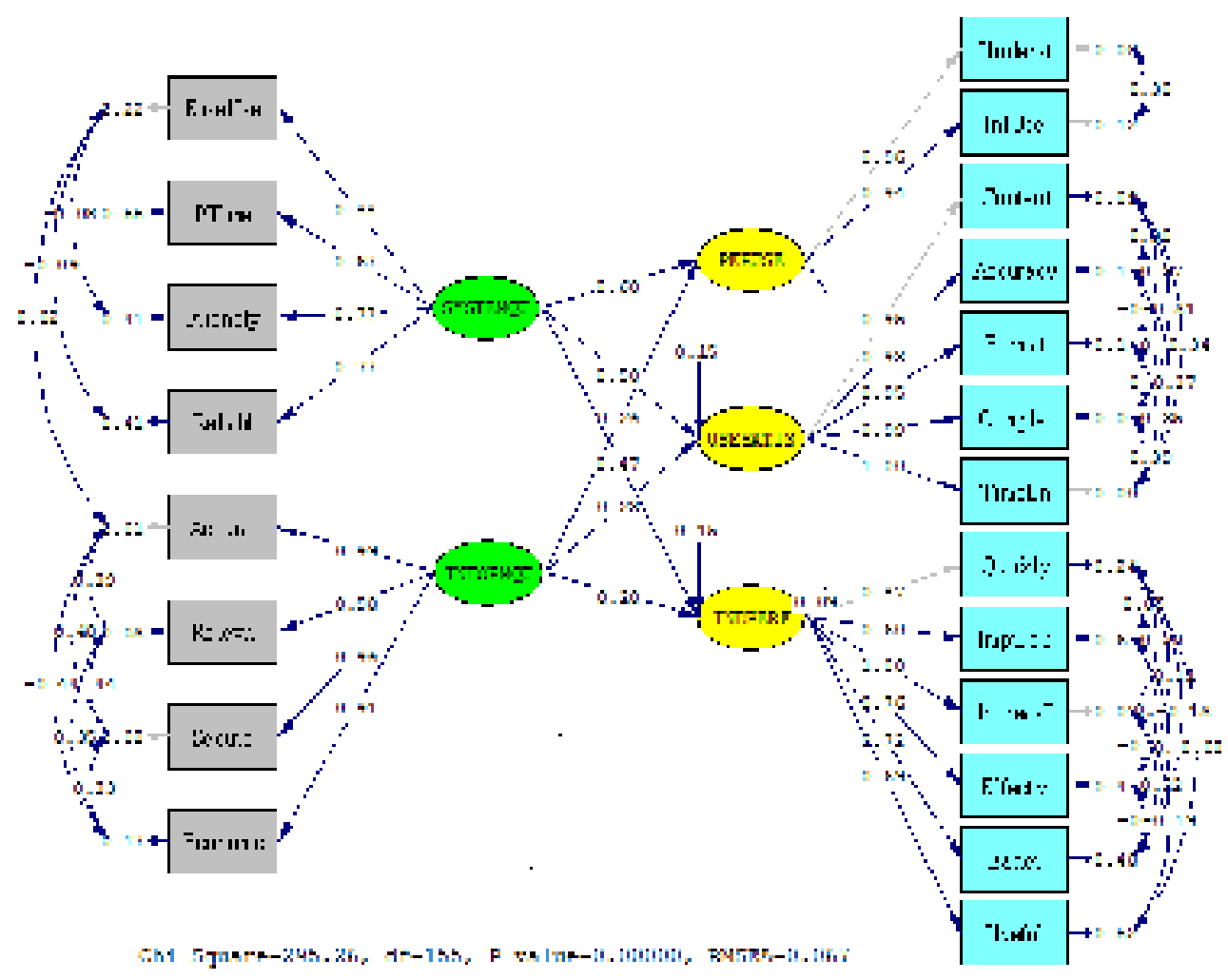


Figure 3. Coefficient of Overall Structural Model

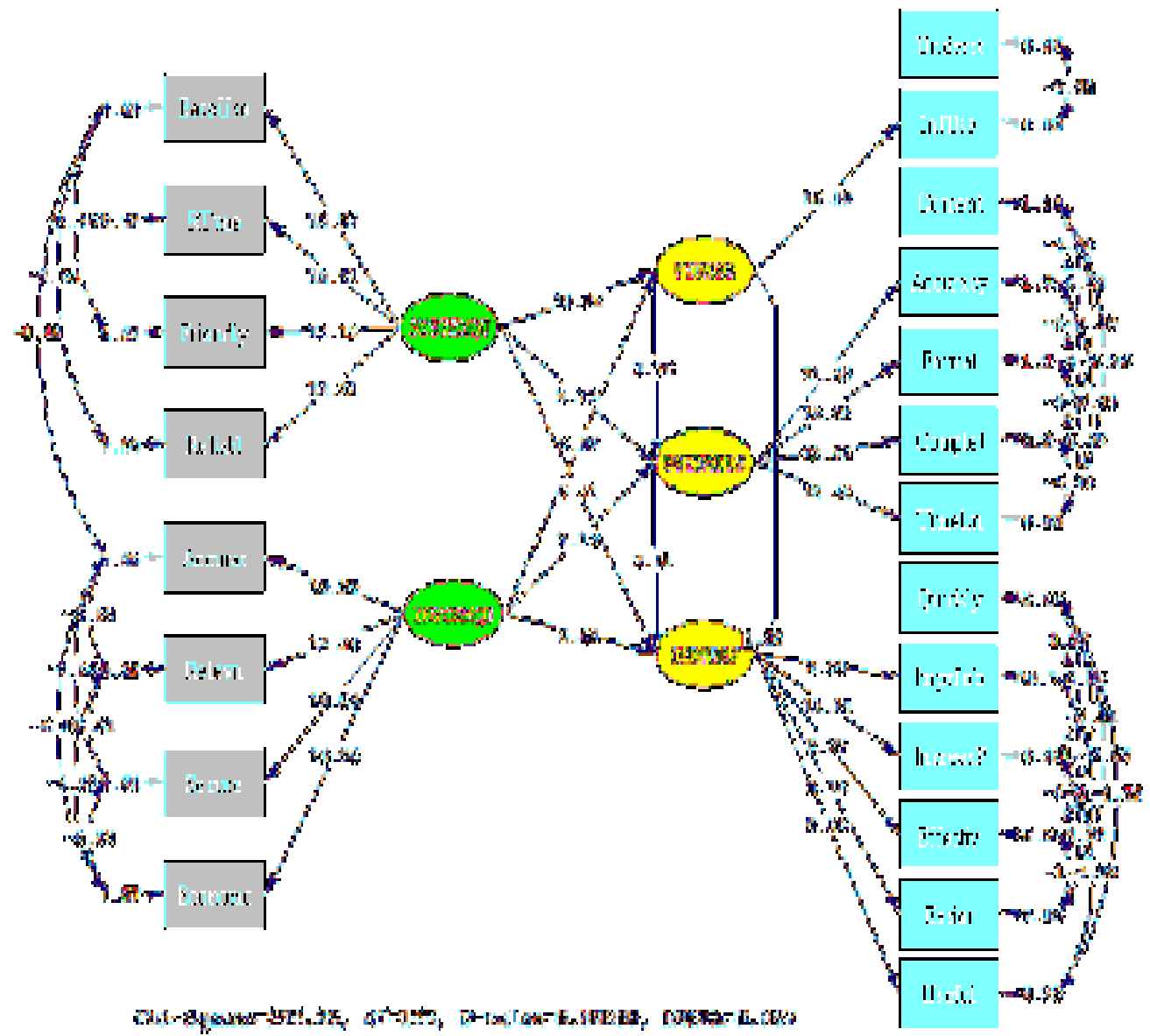

Figure 4. $t_{\text {test }}$ of Overall Structural Model

Table 3. Test Results of the Hypotheses

\begin{tabular}{llccccc}
\hline No. & \multicolumn{1}{c}{ Hypothesis } & $\begin{array}{c}\mathbf{t}_{\text {test }} \\
\geq 1.96\end{array}$ & $\begin{array}{c}\text { Structural } \\
\text { Coefficient }\end{array}$ & Conclusion & Relevant Research \\
\hline $\mathrm{H}_{1}$ & $\begin{array}{l}\text { System Quality } \rightarrow \\
\text { Perceived Usefulness }\end{array}$ & 10.26 & 0.60 & $\begin{array}{c}\text { Significant, } \\
\text { accepted } \\
\text { Data supported }\end{array}$ & $\mathrm{H}_{1}$ & Hadji and Degoulet \\
(2016)
\end{tabular}


Sri Anjarwati: Several Influences of...

\begin{tabular}{|c|c|c|c|c|c|}
\hline No. & Hypothesis & $\begin{array}{r}\mathbf{t}_{\text {test }} \\
\geq 1.96\end{array}$ & $\begin{array}{l}\text { Structural } \\
\text { Coefficient }\end{array}$ & Conclusion & Relevant Research \\
\hline & & & & Data supported & (2013) \\
\hline $\mathrm{H}_{5}$ & $\begin{array}{l}\text { Perceived Usefulness } \rightarrow \\
\text { User Satisfaction }\end{array}$ & 3.76 & 0.15 & $\begin{array}{c}\text { Significant, } \\
\text { accepted } \\
\text { Data supported }\end{array}$ & $\begin{array}{l}\text { Wu and Wang } \\
\text { (2006) }\end{array}$ \\
\hline $\mathrm{H}_{6}$ & $\begin{array}{l}\text { User Satisfaction } \rightarrow \\
\text { Individual Performance }\end{array}$ & 3.61 & 0.15 & $\begin{array}{c}\text { Significant, } \\
\text { accepted } \\
\text { Data supported }\end{array}$ & $\begin{array}{c}\text { Sirsat and Sirsat } \\
\text { (2010) }\end{array}$ \\
\hline
\end{tabular}

Structural Equations

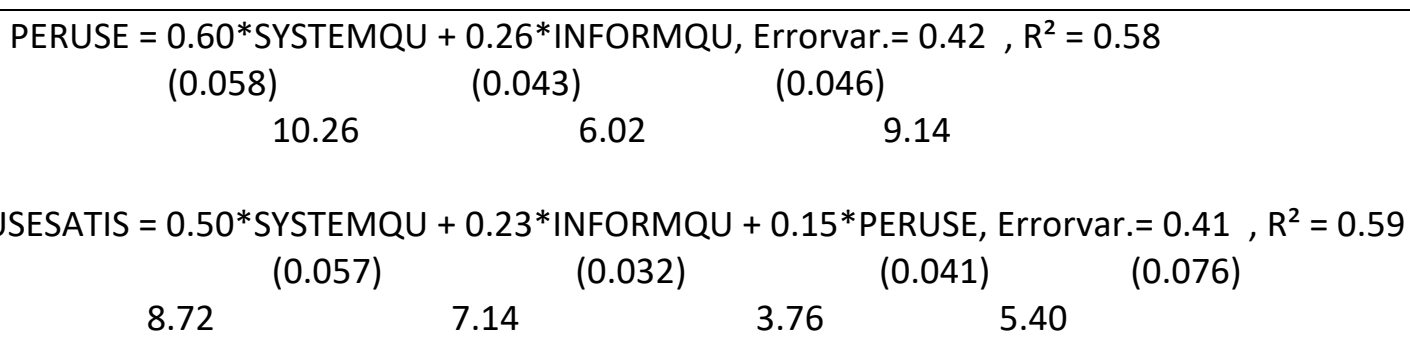
INDPERF $=0.62 *$ USESATIS, Errorvar $=0.62, R^{2}=0.38$
(0.072) (0.11)
$8.66 \quad 5.74$

INDPERF $=0.15 *$ USESATIS $+0.47 *$ SYSTEMQU + 0.20*INFORMQU + 0.090*PERUSE, Errorvar. $=$ $0.38, R^{2}=0.62$
(0.042)
$(0.074)$
(0.036)
(0.050)
(0.064)
3.61
6.31
5.64
1.82
5.87

Source : Self Proceed

\section{Hypotheses Research Results Model 1}

$\mathrm{H}_{1} \quad$ System quality has significant influence on perceived usefulness.

$\mathrm{H}_{2}$ Information quality has significant has influence to perceived usefulness.

$\mathbf{H}_{1}$ test results can be concluded that the quality system has a significant positive influence on perceived usefulness. The coefficient value was 0.60 . It indicates thatthe quality system increases then can improve perceived usefulness. The result of $\mathbf{H}_{\mathbf{2}}$ test can be concluded that the quality information has a significant positive influence on perceived usefulness. Coefficient value was 0.26 . It indicates that quality information increases can improve perceived usefulness. The value of $\mathrm{R}^{2}$ Model 1 was 0.58 . It means that it can explain $58 \%$ of the change of perceived usefulness variable.

Research is supported by researcher Hadji and Degoulet (2016), Istianingsih and Wijanto (2015) which state that quality system and information have a significant positive effect to perceived usefulness and user satisfaction of software. This study contradicts previous research conducted by Wu and Wang (2006) which states that the quality system has no significant effect on perceived usefulness.

\section{Model 2}


$\mathrm{H}_{3}$ System quality has significant influence to user satisfaction.

$\mathrm{H}_{4}$ Information quality has significant influence to user satisfaction.

$\mathrm{H}_{5} \quad$ Perceived usefulness has significant influence to user satisfaction.

$\mathbf{H}_{3}$ system quality testing has a significant positive influence on software user satisfaction. Coefficient value was 0.50 which indicates that the system quality is higher so that the software user satisfaction is increasing.

$\mathbf{H}_{4}$ test results information quality has a significant positive influence on software user satisfaction. Coefficient value was 0.23 which indicates that the quality information is high then the software users satisfaction is increasing.

The results of study is in accordance with research conducted by Sirsat and Sirsat (2010), Roky and Al Meriouh (2015), which states that the quality system and quality information significantly affect user satisfaction. This result contradicts with Meinie (2013), Sebetci and Çetin (2015) which states that the quality information does not significantly affect users satisfaction of software.

$\mathrm{H}_{5}$ perceived usefulness testing have a significant positive influence on software user satisfaction. The value of coefficient was 0.15 which means the higher the use of perceived usefulness of the user satisfaction software increases. This study is consistent with Hadji and Degoulet's research (2016), Wu and Wang (2006) Istianingsih and Wijanto (2008) whereas the perceived usefulness affect user satisfaction.

The value of $R^{2}$ system quality, information quality and perceived usefulness to user satisfaction is 0.59 which shows that $59 \%$ change of contribution influence of three variables to change user satisfaction.

\section{Model 3}

$\mathrm{H}_{6}$ User satisfaction has significant influence to individual performance.

$\mathbf{H}_{6}$ testing user satisfaction has a significant positive influence on individual performance. Coefficient value was 0.15 which indicates that user satisfaction is increased, then it will improve individual performance.

The result of $R^{2}$ value in model was 0.38. It can be interpreted that the improvement of individual performance can be explained by contribution of system quality, information quality, perceived usefulness and user satisfaction was $38 \%$. This research is supported by research conducted by Alkhalaf et al. (2012), Istianingsih and Wiwik (2009), Sirsat and Sirsat (2010) which has the result; user satisfaction have a significant positive effect on individual performance. Meanwhile, the research contradicts Meinie (2013), Roky and Al Meriouh (2015) and Wahyu and Muhammad (2016) with findings that end-user satisfaction has no significant effect on individual performance.

The amount of contribution for all latent variables to individual performance latent variable in model 1 , model 2 and model 3 are shown by value $R^{2}=0.62$ or $62 \%$.

\section{CONCLUSION}

The results of analysis and discussion can be concluded as 1) system quality and information quality has significant influence on perceived usefulness 2) system quality, information quality and perceived has significant influence on user satisfaction 2) user satisfaction has significant influence on individual performance. According to the result of coefficient value of overall model, the highest influence was shown by the influence of system quality on perceived usefulness. 
Sri Anjarwati: Several Influences of...

\section{REFERENCES}

Alkhalaf, S., et al. (2012). Assessing The Impact of e-Learning Systems on Learners: A Survey Study in The KSA. School of ICT, Griffith University, Gold Coast, QLD, Australia and College of computer sciences and information technology, King Faisal University, Saudi Arabia. Procedia - Social and Behavioral Sciences, 47(2012): 98-104.

Bailey, J.E. and S.W. Pearson. (1983). Development of a Tool for Measuring and Analyzing Computer User Satisfaction. Manajemen Science, 29 (May).

Davis, F.D. (1989). Perceived Usefullness, Perceived Ease of Use and User Acceptance of Information Technology. MIS Quarterly, 13(3): 319-339.

Davis, F.D. (1993). User Acceptance of Information Technology: System Characteristics, User Perception and Behavioral Impact. International Journal of Man-Machine Studies, 38(3): 475-487.

Davis, Fred D. (1989). Perceived Usefulness, Perceived Ease of Use, and User Acceptance of Information Technology. MIS Quarterly, 13, (3): 319-340.

DeLone WH, McLean ER (2003). The Delone and McLean Model of Information Systems Success:A Ten-Year Update. JMIS; 19(4): 9-30.

DeLone, W.H., and Ephraim R. Mclean. (1992). Information System Success: The Quest for the Dependent Variable. Information System Research, 3(1), 60-95.

Gelinas, Ulrich and Dull, B. Richard. (2012). Accounting Information Systems. $9^{\text {th }}$ edition. Mason: South Western Cengage.

Ghozali, I. (2014). Model Persamaan Struktural Konsep dan Aplikasi dengan Program Lisrel 9.10, Badan Penerbit UNDIP, Semarang.

Goodhue, D.I and Thompson. R.L. (1995). Task-Technology and Individual Performance. MIS Quarterly, 19 (2): 213236.
Hadji, B. and Degoulet, P. (2016). Information System End-user Satisfaction and Continuance Intention: a Unified Modeling Approach. INSERM-UMRS 1138, CRC, Team 22, Paris and France, Paris Descartes University, Paris, France. Journal of Biomedical Informatics, doi: http://dx.doi.org/10.1016/i.jbi.2016.03.0 21.

Hair, J.F., W.C. Black, B.J. Babin, R.F Anderson and R.L Tathan. (2006). Multivariate Data Analysis. $6^{\text {th }}$ Edition. Person International Edition.

Hall, James A. (2007). Accounting Information Systems. Edisi 4. Buku satu. Penerjemah Dewi Fitriani dan Denny. Jakarta: Salemba Empat.

Heidmann, M. (2008). The Role of Management Accoounting System in Strategic Sensemarking. Elsevier.

Chou, C. P., \& Bentler, P. M. (1995). Estimates and Tests in Structural Equation Modeling: Concepts, Issues and applications. SAGE Publications. 33-75.

Istianingsih dan Setyo Hari Wijanto. (2008). Pengaruh Kualitas Sistem informasi, Kualitas Informasi, dan Percived Usefulness Terhadap Kepuasan Pengguna Software Akuntansi. Simposium Nasional Akuntansi IX, Pontianak.

Istianingsih dan Utami, Wiwik. (2009). Pengaruh Kepuasan Pengguna Sistem Informasi terhadap kinerja individu (Studi Empiris Pada Pengguna Paket Program Aplikasi Sistem Informasi Akuntansi Di Indonesia). Simposium Nasional Akuntansi XII.

Jogiyanto. (2007). Sistem Informasi Keperilakuan. Edisi Revisi. Yogyakarta: Andi Offset.

Laudon, Kenneth C., dan Jane P. Laudon (2015). Management Information Systems, Managing the Digital Firm. Penerjemah Lukki Sugito, Merry Rindy Antika dan Ratna Sarawati. Edisi 13. Jakarta: Salemba Empat. 
Meinie Susanty. (2013). Pengujian Model De Lone dan Mc Lean dalam Pengembangan Sistem Informasi IFCA. STIE Trisakti. Jurnal Bisnis dan Akuntansi, 15 (92): 14215.

Nainggolan, S. (2012). Sistem Bernegara Amburadul Penyebab Korupsi. Accses from http://www. tribunnews.com/nasional/2012/05/09/sis tem-bernegara-amburadul-penyebabkorupsi, accesed: December, 14, 2017.

Negash, Solomon, et al. (2003). Quality and effectiveness in Web-based Customer Support System. Journal of Information and Management, 40(2003):758-768.

Özel Sebetci, Mustafa Çetin. (Article In Press, 2015). Developing, applying and measuringan e-Prescription Information Systems Success Model from the persperctives of Physicians and Pharmacists. Söke Faculty of Bussiness Administration, Adnan Menderes University Aydın, Turkey. http://dx.doi.org/10.1016/ j.hlpt.2015.10.008.

Stacie, Petter., DeLone, William H., dan McLean, Ephraim R. (2008). Measuring Information Systems Success: Models, Dimensions, Measures, and Interrelationships. European Journal of Information System, 17(3): 236-263.

Stacie, Petter., DeLone, W., \& McLean, E.R. (2013). Information Systems Success: The Questfor Independent Variables. Journal of Management Information Systems, 29 (4): 7- 62.

Roky, Hanae and Youssef Al Meriouh. (2015). Evaluation by Users of An Industrial Information System (XPPS) Based on The DeLone and McLean Model for IS Success. 4th World Conference on Business, Economics and Management, WCBEM. Procedia Economics and Finance, 26(201): 903-913.
Romney, Marshall B., dan Paul John Steinbart. (2015). Accounting Information Systems. $13^{\text {th }}$ edition. England: Pearson Educational Limited.

Sekaran, Uma. (2013). Research Methods for Bussiness: A Building Appoach. 6th Edition. Penerjemah Kwan Men Yon. New York: John Wiley and Sons, Inc.

Sirsat, Sanjay S and Manisha S Sirsat. (2010). A Validation of The Delone And Mclean Model On The Educational Information System Of The Maharashtra State (India). Department of Management Science Dr. B.A.M. University, Aurangabad India. International Journal of Education and Learning Systems, 1(2015): 9-18.

Putra, W. M. dan Muh. Alfian. (2016). Pengujian Kesuksesan Implementasi Sistem Informasi Akuntansi Lembaga Keuangan Mikro: Modified Delone Mcleon Model. Jurnal Akuntansi \& Investasi, DOI: 10.18196/ jai.2016.0044. 53-65.

Wijanto, Setyo Hari., (2015). Metode Penelitian menggunakan Structural Equation Model dengan Lisrel 9, Jakarta: Lembaga Penerbit FEUI.

Wijanto, Setyo Hari. (2015). Metode Penelitian menggunakan Structural Equation Model dengan Lisrel 9. Jakarta: Lembaga Penerbit FEUI. 
Sri Anjarwati: Several Influences of... 